\title{
The impact of proliferation and cancer stem cell upon the resistence to chemotherapy in salivary mucopepidermoid carcinoma
}

\author{
Doaa A M Esmaeil ${ }^{1}$, Rehab A Ahmed ${ }^{* 2}$, Mohamed I Mourad ${ }^{1}$, Essam T Gaballah ${ }^{1}$ \\ ${ }^{1}$ Department of oral pathology, Faculty of Dentistry, Mansoura University, Mansoura, Egypt \\ ${ }^{2}$ Department of pathology, Faculty of Medicine, Mansoura University, Mansoura, Egypt
}

Received: November 29, 2018

Accepted: January 13, 2019

Online Published: January 21, 2019

DOI: $10.5430 /$ jst.v9n1p13

URL: https://doi.org/10.5430/jst.v9n1p13

\begin{abstract}
Background and aim: Mucoepidermoid carcinoma is a common salivary tumor that affects both adults and children. Proliferation is one of the most fundamental biological processes of growth and maintenance of tissue homeostasis. CD-44 may be used as an indicator of aggressive behavior of some human malignancy. Multidrug resistance is one of the major obstacles for successful cancer chemotherapy. The present study was carried out for evaluation of the biological rules and the clinicopathological significance of Ki-67, CD-44 and MDR-1 expression in the different histopathological grades of MECs.

Patients and methods: Eighty paraffin embedded MEC tissues were collected and classified to three groups according to their histological grades. Tissue sections were stained with Ki-67, CD-44 and MDR-1 then examined microscopically and analyzed statistically.

Results: High grade MEC cases showed the highest expression for Ki-67, CD-44 and MDR-1. Additionally, significant differences were found between the histopathological grades as well as between lymph node stages of the studied cases and the expression of the three utilized markers.

Conclusion: Ki-67, CD-44 and MDR-1can be used to evaluate the degree of differentiation and to predict the prognosis of MECs, furthermore, high grade MEC cases with high proliferative indices might be resistant to chemotherapy.
\end{abstract}

Key Words: Salivary, Mucoepidermoid carcinoma, Ki-67, CD-44, MDR-1, Stem cell

\section{INTRODUCTION}

Mucoepidermoid carcinoma (MEC) accounts for 5\%-15\% of all salivary tumors and $30 \%-35 \%$ of malignant salivary tumors. ${ }^{[1]}$ It is the most common salivary gland malignancy in children. ${ }^{[2,3]}$ It is believed to arise from the reserve cells of excretory ducts. ${ }^{[3]}$ The stiff growth of MEC with aggravated resistance to therapy is a major clinical challenge that might be correlated with the function of cancer stem cells
(CSCs). However, whether or not cancer stem cells play a role in the pathobiology of salivary MEC has not yet been investigated. ${ }^{[4-6]}$ Cell proliferative activity is a reliable prognostic factor in head and neck tumors. ${ }^{[7]}$ The most widely practised measurement involves the immunohistochemical assessment of Ki-67 antigen. ${ }^{[8,9]} \mathrm{Ki}-67$ is a universal cyclindependent kinase inhibitor and a proliferative cell marker. It has been useful in predicting clinical aggressiveness in

*Correspondence: Rehab A Ahmed; Email: rehaballah1975@gmail.com; Address: Pathology department, Faculty of medicine, Mansoura University, Mansoura, Egypt. 
various human tumors, including laryngeal carcinoma and determines the recurrence rate after radiotherapy in adenocarcinoma patients. ${ }^{[10-12]}$ Recently, stem cell biology concepts have been applied with a new force to the field of cancer biology. ${ }^{[13]}$ CSCs are important in the development, invasion, drug resistance, and may also predict treatment outcome of carcinomas. ${ }^{[14,15]}$ However, the existence of CSCs, and their phenotypes remain unclear. Also, their putative influence on the behavior of malignant salivary gland neoplasms deserves further investigation. ${ }^{[16,17]}$ Segregation of CSCs can be achieved using protein markers that are differentially expressed in stem cells compared to the non-cancer stem cell population. Some studies have reported correlation between CSCs and unregulated expression of CD-44. ${ }^{[16,18,19]}$

Cluster designation-44 (CD-44) is a cell adhesion molecule and acts as the major hyaluronan receptor and as a receptor for many other extracellular matrix (ECM) components such as type I and IV collagens, fibronectin and laminin. It also interacts with signaling molecules such that possess protein tyrosine kinase activity and binds soluble growth factors. ${ }^{[20]}$ Tumor cells that express CD44 exhibit a cancer stem-cell behavior. ${ }^{[16]} \mathrm{CD}-44$ has been reported to be involved with tumor growth and metastasis and has also been implicated as a cancer stem cell marker in head and neck squamous cell carcinoma. $^{[21]}$

Multidrug resistance (MDR) is one of the major drawbacks for successful cancer chemotherapy. ${ }^{[22]}$ Multidrug resistance protein-1 (MDR-1), a membrane-bound energydependent efflux transporter, is over expressed in several kinds of multidrug-resistant cell lines. It is P-Glycoprotein and related to multidrug-resistance phenotype of various cancers. ${ }^{[17,22,23]}$ In breast cancer, MDR-1 leads to tumor invasion, metastasis and poor clinical outcome. ${ }^{[24]}$ Understanding the MEC pathobiology, particularly mechanisms of resistance to therapy, is critical to improve the survival and the quality of life of MEC patients. ${ }^{[4]}$ To the best of our knowledge, the literatures that studied the effects of proliferation and cancer stem cells upon resistance to chemotherapy in salivary MEC are very rare. Therefore, the present study will be a trial to explore the posible roles of Ki-67 (proliferation marker), CD-44 (cancer stem cell marker) in drug resistance of MEC through MDR-1 expression.

\section{Patients And Methods}

\subsection{Data retrieval}

This retrospective study was carried out on eighty cases of previously diagnosed salivary MECs. All cases were surgically excised. The paraffin embedded blocks were collected from Oral Pathology Department, Faculty of Dentistry, Mansoura University and Pathology laboratory of the Oncology center, Faculty of Medicine, Mansoura University, Mansoura, Egypt in the period between January 2011 and December 2016. Ten normal salivary gland tissues were used as a control group. All obtained from excised salivary glands with sialolithiasis and chronic sialadenities.

The clinical data of the studied cases were collected retrospectively from the computerized database of the centers registry regarding age, gender, site, signs, symptoms, lymph node involvement, tumor size, and distant metastasis. The studied cases were evaluated clinically according to TNM staging system of the AJCC. ${ }^{[25,26]}$

\subsection{Immunohistochemical staining}

Serial sections of $4 \mu \mathrm{m}$ thick were obtained from each paraffin block and stained for haematoxylein and eosin stain to confirm the diagnosis, to assess the presence of the representative tumor in each block and to grade the tumor into low grade, intermediate grade and high grade according to Armed Forces Institute of Pathology (AFIP) criteria. ${ }^{[7]}$

Table 1. Characters of the utilized antibodies in the present study

\begin{tabular}{|c|c|c|c|c|}
\hline $\begin{array}{l}\text { Immunohistochemical } \\
\text { markers }\end{array}$ & Clone & Dilution & $\begin{array}{l}\text { Cellular } \\
\text { localization }\end{array}$ & Source \\
\hline $\begin{array}{l}\text { Ki-67 (Mouse Monoclonal } \\
\text { Antibody) }\end{array}$ & SP6 Immunogen & \multirow{2}{*}{$\begin{array}{l}\text { Ready to use antibody } \\
\text { and prediluted in a tris } \\
\text { buffered solution at } \mathrm{pH} \\
7.4\end{array}$} & Nuclear & \multirow{2}{*}{$\begin{array}{l}\text { Master Diagnostica systems, } \\
\text { Avda, Conocimiento. Ciencias } \\
\text { de la Salud } 18016 \text { Granada }\end{array}$} \\
\hline $\begin{array}{l}\text { CD-44 (Anti Human, } \\
\text { Monoclonal, Anti-CD44 } \\
\text { standard isoform) }\end{array}$ & 156-3C11 & & Membranous & \\
\hline $\begin{array}{l}\text { MDR-1 (Mouse, Monoclonal, } \\
\text { (P-Glycoprotein) }\end{array}$ & EP271 & Working dilution: 1:50 & $\begin{array}{l}\text { Membranous } \\
\text { and } \\
\text { Cytoplasmic }\end{array}$ & $\begin{array}{l}\text { Bio-Genex, Emergo Europe, } \\
\text { Molenstraat 15, NL-2513 BH } \\
\text { The Hague, The Netherlands. }\end{array}$ \\
\hline
\end{tabular}


Sections of $3-4 \mu \mathrm{m}$ thick were obtained from the accurate paraffin block and mounted on positively charged slides (obtained from Bio Genex Laboratory (4600 Caryon Road, San Ramon, UAS, 2015) to be stained immunohistochemically for Ki67, CD44 and MDR-1. The slides were deparaffinized in xylene and rehydrated in descending grades of alcohol into water. Blocking endogenous peroxidase using $3 \%$ hydrogen peroxide in methanol for 5 minutes was done followed by washing in PBS. Antigen retrieval was performed with EDTA buffer at pH 9 for Ki-67, while CD-44 and MDR-1 slides were immersed in Citrate buffer solution at $\mathrm{pH} 6$ at $94^{\circ} \mathrm{C}$ for 25 minutes. Slides were allowed to cool then washed in PBS. The specific antibodies (Ki-67, CD-44 and MDR-1) were applied for 1 hour at room temperature followed by washing in PBS 3 times. The characters of the used antibodies were summarized in Table 1. Immunostaining was performed using the Envision horseradish peroxidase (HRP) Detection System (Dako, Carpinteria, CA) and the procedures were done according to the manufacturer instructions. DAB was used as a chromogen for 5 minutes to visualize the immunoreaction and the slides were counterstained with Mayer's haematoxylin for 1 minute and cover slipped with the mounting media.

A negative control was tested with each run by omitting the primary antibody. Slides from hyperplastic tonsillar tissues were used as positive controls for Ki-67 and CD-44, while slides from colon carcinoma tissues were used as a positive control for MDR-1. Evaluation of immunohistochemical reaction was done using the Computer Assisted digital image analysis (Digital morphometric study). ${ }^{[27]}$

\subsection{Statistical analysis}

SPSS program version 17 was used for statistical analysis of the data. The descriptive statistics were calculated in the form of Frequency (Number-percent). Quantitative statistics were calculated in the form of mean \pm standard deviation (SD) for parametric data and Median and range (Minimummaximum) for nonparametric ones. Statistical comparison between the different groups and the significance of difference was tested using one of the following tests; ANOVA test was used to compare between more than two groups of numerical (parametric) data followed by post-hoc turkey. Kruskal Wallis was used to compare between two groups of numerical (non-parametric) data followed by Mann-Whitney for pair wise comparisons. The Mann-Whitney test was used to compare between two groups of numerical (parametric) data. Whereas, Inter-group comparison of categorical data was performed by using chi square test (X2-value). $p$ value $\leq .05$ was considered statistically significant.

\section{RESUlts}

\subsection{Clinicopathological characteristics of the studied cases}

The age range of the studied cases was 13 to 78 years with a mean age of $48.07 \pm 15.05$. There was a slight tendency for occurrence among females $(55 \%)$ with a female to male ratio of 1.22:1. The most common site for the studied cases was the parotid gland (58\%), while retromolar area was the least involved site (4\%). Tumors of the palate and submandibular glands accounted for $30 \%$ and $8 \%$ respectively. Stage III was the most common accounting for $37 \%$ followed by stage IV, II and I 35\%, 25\%, 3\% respectively. Metastasis was present in only $13 \%$. Regarding regional lymph node involvement, the majority of cases were $\mathrm{N} 1(40 \%)$ while $\mathrm{N} 0$ and $\mathrm{N} 2$ were $37 \%$ and $23 \%$ respectively. As regard tumor size, $43 \%$ of the studied cases were T2 $(2-4 \mathrm{~cm}$ in diameter) followed by T3, T4 and T1 accounting for 25\%, $17 \%$ and $15 \%$ respectively. Grade III accounted for $45 \%$ followed by grade I and II representing $35 \%$ and $20 \%$ respectively (data not shown in table).

Table 2. Association between the histopathological groups of the current study and Ki-67, CD-44 and MDR-1 expression

\begin{tabular}{|c|c|c|c|c|c|c|c|c|c|c|c|c|c|c|c|c|c|c|c|c|c|c|c|c|}
\hline \multirow{3}{*}{$\begin{array}{l}\text { Variables } \\
\text { HP. } \\
\text { Groups }\end{array}$} & \multicolumn{3}{|c|}{$\begin{array}{l}\text { Ki-67 Percentage of } \\
\text { positive cells }\end{array}$} & \multirow{2}{*}{$P$} & \multicolumn{3}{|c|}{$\begin{array}{l}\text { Ki-67 Integrated } \\
\text { Density }\end{array}$} & \multirow{2}{*}{$\begin{array}{l}P \\
\end{array}$} & \multicolumn{3}{|c|}{$\begin{array}{l}\text { CD- } 44 \text { Percentage } \\
\text { of positive cells }\end{array}$} & \multirow[t]{2}{*}{$P$} & \multicolumn{3}{|c|}{$\begin{array}{l}\text { CD-44 Integrated } \\
\text { Density }\end{array}$} & \multirow[t]{2}{*}{$P$} & \multicolumn{3}{|c|}{$\begin{array}{l}\text { MDR-1 Percentage } \\
\text { of positive cells }\end{array}$} & \multirow{2}{*}{$P$} & \multicolumn{3}{|c|}{$\begin{array}{l}\text { MDR-1 Integrated } \\
\text { Density }\end{array}$} & \multirow[t]{2}{*}{$P$} \\
\hline & $\mathrm{L}$ & IM & $\mathrm{H}$ & & $\mathrm{L}$ & IM & $\mathrm{H}$ & & $\mathrm{L}$ & IM & $\mathrm{H}$ & & L & IM & $\mathrm{H}$ & & $\mathrm{L}$ & $\mathrm{IM}$ & $\mathrm{H}$ & & L & IM & $\mathrm{H}$ & \\
\hline & & & & .001 & & & & .001 & & & & .001 & & & & .001 & & & & .001 & & & & .001 \\
\hline Median & 5.7 & -58.7 & 77.5 & & 3.3 & 3.9 & 111.3 & & 2.5 & 7.6 & 13.4 & & 8.6 & 177.3 & 352.3 & & 4 & 25.5 & 75.6 & & 1 & 38.8 & 45. & \\
\hline P1 & & .007 & & & & 0.4 & & & & .02 & & & & .001 & & & & .02 & & & & .007 & & \\
\hline P2 & & & .001 & & & & .001 & & & & 0.01 & & & & .001 & & & & .018 & & & & .54 & \\
\hline P3 & & & .08 & & & & .002 & & & & .001 & & & & .5 & & & & .001 & & & & .001 & \\
\hline
\end{tabular}

Note. P: Probability, HP: histopathological, L: low grade, IM: intermediate grade, H: high grade, Test used: Kruskalwallis test followed by mann-whitney, P1: significance between low and intermediate grade, P2: significance between low and high grade, P3: significance between high grade and intermediate grade. 
Table 3. Association between the lymph node groups of the current study and Ki-67, CD-44 and MDR-1 expression

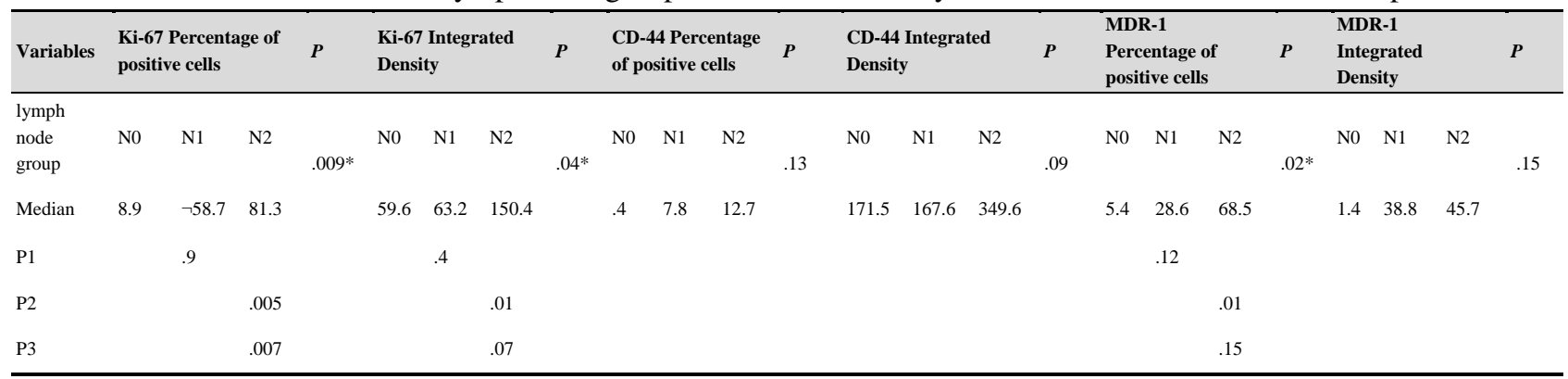

Note. P: Probability , Test used: Kruskalwallis test followed by mann-whitney, P1: significance between N0 \& N1, P2: significance between N0 \& N2, P3: significance between N1 \& N2

\subsection{Immunohistochemical evaluation of the used mark- ers}

Considering the expressions of Ki-67, CD-44 and MDR-1, high grade MEC cases showed the highest levels of expression, while the low grade cases had the lowest levels of expression (see Figure 1). Statistically significant difference was reported between the different histopathological groups in relation to the expression of the three utilized immunohistochemical markers.

Table 4. Correlations between Ki-67, CD-44 and MDR-1 expression and tumor size, regional lymph node involvement, distant metastasis, clinical stage and histopathological grade of the studied MEC cases

\begin{tabular}{|c|c|c|c|c|c|c|c|c|c|c|c|c|}
\hline \multirow{3}{*}{ Variables } & \multicolumn{4}{|c|}{ Ki-67 } & \multicolumn{4}{|c|}{ CD-44 } & \multicolumn{4}{|c|}{ MDR-1 } \\
\hline & \multicolumn{2}{|c|}{$\begin{array}{l}\text { Percentage of } \\
\text { positive cells }\end{array}$} & \multicolumn{2}{|c|}{$\begin{array}{l}\text { Integrated } \\
\text { density }\end{array}$} & \multicolumn{2}{|c|}{$\begin{array}{l}\text { Percentage of } \\
\text { positive cells }\end{array}$} & \multicolumn{2}{|c|}{$\begin{array}{l}\text { Integrated } \\
\text { density }\end{array}$} & \multicolumn{2}{|c|}{$\begin{array}{l}\text { Percentage of } \\
\text { positive cells }\end{array}$} & \multicolumn{2}{|c|}{$\begin{array}{l}\text { Integrated } \\
\text { density }\end{array}$} \\
\hline & $\mathbf{r}$ & $p$ & $\mathbf{r}$ & $p$ & $\mathbf{r}$ & $p$ & $\mathbf{r}$ & $p$ & $\mathbf{r}$ & $p$ & $\mathbf{r}$ & $p$ \\
\hline Tumor size & .12 & .461 & .20 & .20 & .15 & .363 & -027 & .867 & .13 & .438 & -002 & .991 \\
\hline $\begin{array}{l}\text { Regional lymph } \\
\text { node } \\
\text { involvement }\end{array}$ & .40 & .011 & .380 & .016 & .28 & .08 & .207 & .2 & .44 & .004 & .303 & .058 \\
\hline Metastasis & .21 & .18 & .259 & .106 & .12 & .456 & .082 & .616 & .2 & .224 & .234 & .147 \\
\hline Clinical stage & .25 & .12 & .30 & .062 & .13 & .41 & -030 & .856 & .3 & .084 & .174 & .282 \\
\hline $\begin{array}{l}\text { Histopathological } \\
\text { Grade }\end{array}$ & .86 & $<.001$ & .783 & $<.001$ & .912 & $<.001$ & .749 & $<.001$ & .91 & $<.001$ & .635 & $<.001$ \\
\hline
\end{tabular}

Furthermore, multiple comparison tests showed significant difference between every two histopathological groups in relation to the used antigens (see Table 2). No-significant differences were noted between tumor sizes, clinical stages and metastasis regarding the employed immunohistochemical markers (data not shown in tables). Regarding lymph node involvement, Table 3 shows that there is a significant association between Ki 67 expression (both density and percentage) and lymph node involvement with a significant difference between the different groups. In addition, there was a significant association between the percentage of MDR-1 expression and lymph node involvement with a significant difference only between group N0 and N2. On the other hand, there was no significant association with CD44 expression.

Moreover, Sperman's correlation test yielded a significant positive correlation between the employed markers and the histopathological groups. Ki 67 and MDR-1 as well showed significant positive correlation with the regional lymph nodes involvement stage, while CD44 didn't (see Table 4). In addition, significant positive inter-correlation between the utilized markers was detected (see Table 5).

Table 5. Correlation between Ki-67, CD-44 and MDR-1 expressions among the studied MEC cases

\begin{tabular}{|c|c|c|c|}
\hline & \multicolumn{2}{|c|}{$\begin{array}{c}\text { CD-44 integrated } \\
\text { density expression }\end{array}$} & MDR-1 expression \\
\hline $\begin{array}{l}\text { Ki-67 integrated } \\
\text { density expression }\end{array}$ & $\mathrm{r}$ & .571 & .603 \\
\cline { 2 - 4 } & $p$ & $<.0001$ & $<.0001$ \\
\hline $\begin{array}{l}\text { CD-44 integrated } \\
\text { density expression }\end{array}$ & $\mathrm{r}$ & & .523 \\
\cline { 2 - 2 } \cline { 4 - 4 } & $P$ & & .001 \\
\hline
\end{tabular}



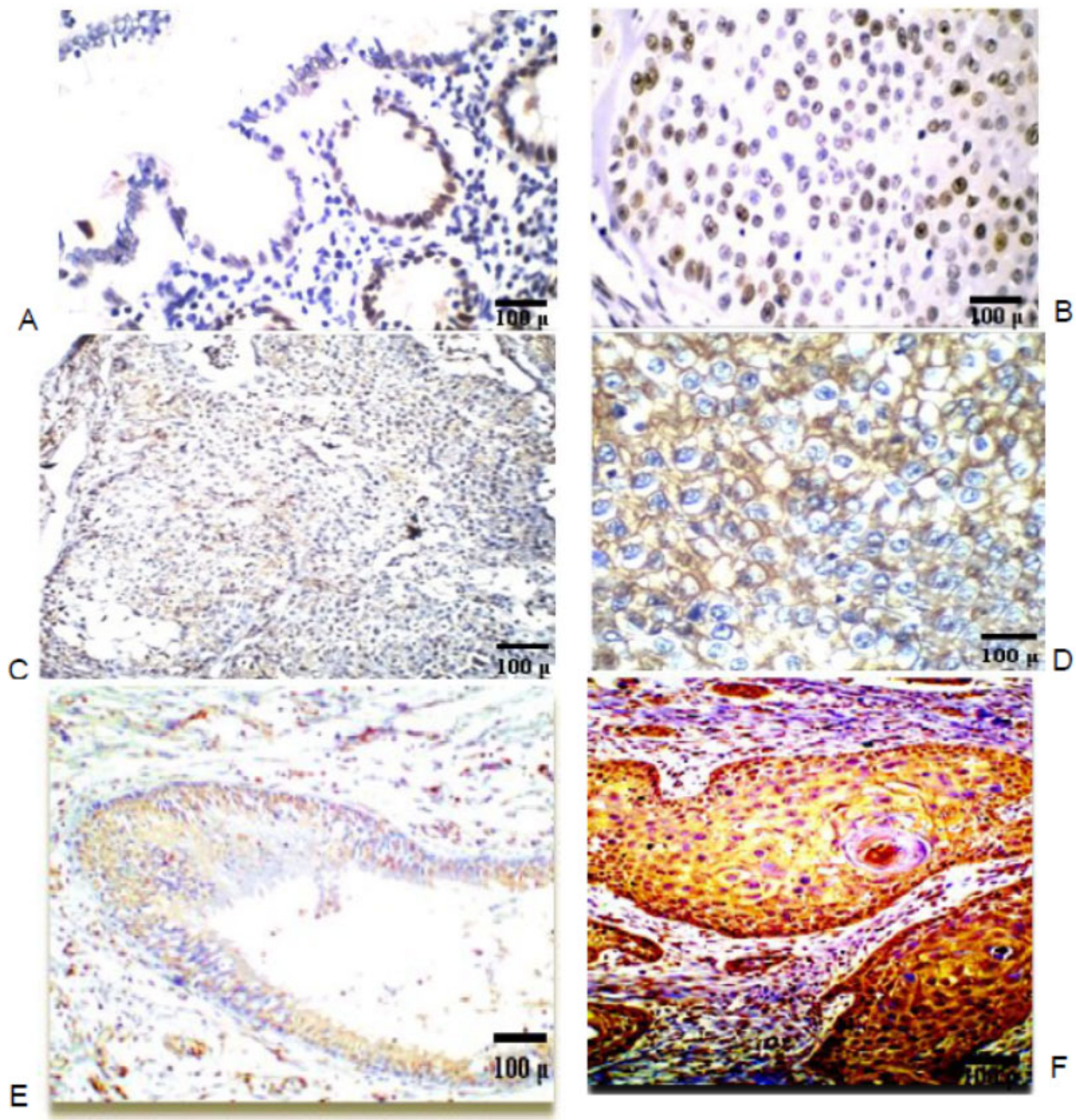

Figure 1. (A) Low grade MEC case shows positive nuclear reaction to Ki-67 mainly in the lesional cells which line the cystic cavities in $6 \%$ of cells with a median density 3.3 (HRP, DAB $\times 400$ ). (B) High grade MEC case shows positive nuclear reaction to Ki-67 in 70\% of the epidermoid cells with a median density 111.3 (HRP, DAB $\times 400$ ). (C) Low grade MEC case shows weak membranous CD-44 expression in 3\% of the lesional cells with a median density 8.6 (HRP, DAB $\times$ 200). (D) High grade MEC case shows extensive membranous CD-44 expression in $95 \%$ of cells with a median density 352.3 (HRP, DAB $\times 400$ ). (E) Low grade MEC case shows weak membranous and cytoplasmic MDR-1 expression in $15 \%$ of the cells lining cystic space with a median density $1(\mathrm{HRP}, \mathrm{DAB} \times 200)$. (F) High grade MEC case shows strong and diffuse membranous and cytoplasmic MDR-1 expression in 95\% of the epidermoid cells with a median density 45 (HRP, $\mathrm{DAB} \times 400)$.

\section{Discussion}

Mucoepidermoid carcinoma shows wide and diverse biological behavior, ${ }^{[28,29]}$ therefore, MEC demands better understanding of its pathobiology and development of new mechanism-based therapies. ${ }^{[5,6]}$ Therefore we tried to find a role of the proliferation marker (Ki67), the cancer stem cell and adhesion molecule (CD44) and MRD-1 protein in the pathogenesis of MEC.

High grade MEC cases of the present study were showed 
higher expression of Ki-67 than intermediate and low grades. This was in consistence with Kaza et al. ${ }^{[30]}$ Siddique et al. ${ }^{[31]}$ Luukkaa et al. ${ }^{[32]}$ Triantafillidou et al. ${ }^{[33]}$ and Skalova et al. ${ }^{[34]}$ who detected progressive increase in $\mathrm{Ki}-67$ immunoreactivity from low to high-grade tumors among their MECs. Moreover, Kaza et al. ${ }^{[30]}$ Faur et al. ${ }^{[35]}$ as well as and Hicks and Flaitz ${ }^{[36]}$ evaluated and assessed proliferation of MEC cells, reported that the percentage of Ki-67 immunoreactive tumor cells were prominent among their high grade cases and decreased among their low grade cases. Also, Cardoso et al. ${ }^{[8]}$ detected elevation of cell proliferation with the malignancy grade of their MEC cases through the percentage of PCNA positive tumor cells. Concerning Ki-67 expression in the current study, there was significant positive correlation with histopathological grades and regional lymph node involvement. Meanwhile, non-significant correlation was detected with tumor size, metastasis and clinical stage. This is supported with the findings of Bonhin et al. ${ }^{[37]}$ and Kim et al. ${ }^{[38]}$ who found a significant positive correlation between Ki-67 cell proliferation and histological tumor differentiation of squamous cell carcinoma. In addition, Kim et al. ${ }^{\text {[38] }}$ stated that Ki-67 expression was significantly associated with lymph node involvement of their studied SCCs. In the same context, Maeda et al. ${ }^{[39]}$ reported that PCNA expression had a significant positive correlation with histological grades and lymph node involvement of their studied gastric carcinoma cases. On the other hand, Faur et al. ${ }^{[35]}$ found that Ki-67 immunoreactivity was significantly correlated with clinical stage and tumor size of their MECs. Also, Maeda et al. ${ }^{[39]}$ detected a significant correlation between PCNA expression and tumor clinical stage as well as with metastasis among their studied gastric carcinomas.

In the current work, high grade MEC cases had the highest CD-44 expression. This is consistent with the findings of Binmadi et al. ${ }^{[40]}$ whose high grade MEC cases revealed moderate to strong CD-44 expression. On the contrary, Rodrigo et al. ${ }^{[41]}$ found reduction of CD-44 expression in their poorly differentiated SCC cases. They hypothesized that the lack of a functional CD-44. Also, Jang et al. ${ }^{[42]}$ did not observe any correlations between CD-44 expression and age, tumor size, clinical stage as well as lymph node involvement of their studied breast cancer cases which is consistent with our results. On the opposite hand, Spafford et al. ${ }^{[43]}$ found that CD-44 was correlated positively with regional lymph node involvement. These discrepancies could be explained by Rodrigo et al. ${ }^{[41]}$ on the basis of site, number of analyzed cases, clinical and histopathological tumor grade, extension of lymph node dissection, staining methods, used antibodies, and differences in staining evaluation.

The highest expression of MDR-1 was among high grade studied MEC cases, while the lowest expression was in low grade cases. These findings were statistically significant. Similarly, Furusaka et al. ${ }^{[4]}$ reported high percentage of MDR-1 in intermediate and high grades of malignancy. On the contrary, Yang et al. ${ }^{[4]}$ found that MDR-1 was not expressed in breast carcinoma cells; they suggested that it did not play a significant role in multidrug resistance of breast cancer.

In the current work, MDR-1 expression was positively correlated with regional lymph node involvement and histopathological grades. This agrees with $\mathrm{Li}^{[46]}$ who found that MDR-1 was expressed in the different histological grades of laryngeal SCC and showed significant positive correlation with lymph node. In addition, Lu et al. ${ }^{[4]}$ noted that MDR-1 was significantly correlated positively with lymph node in their studied invasive ductal breast cancer cases.

In the current study, regarding MDR-1 expression, no correlations were reported between tumor sizes, clinical stages and metastasis, this contradicts with $\mathrm{Li}^{[46]}$ who found that MDR-1expression was significantly correlated to the clinical stage and metastasis in laryngeal SCC cases.

In the present work, significant positive correlation between the utilized immunohistochemical markers (Ki-67, CD-44 and MDR-1) was noted. This could be interpreted by; Booth et al. ${ }^{[4]}$ and Dowsett et al. ${ }^{[9]}$ who deduced that Ki-67 is important for determining prognosis of the tumors, prediction of resistance to chemotherapy. ${ }^{[9]}$ Furthermore, Soave et al. ${ }^{[16]} \mathrm{Li}$ et al. ${ }^{[18]}$ and Al-Hajj et al. ${ }^{[19]}$ reported that CD-44 unregulated expression had a correlation with CSCs, which are important indrug resistance of carcinomas. ${ }^{[49]}$

In addition, Yildiz et al. ${ }^{[50]}$ reported that CD-44 expression was connected with a high rate of cell proliferation and poor prognosis. Also, Misra et al. ${ }^{[51]}$ stated that MDR in cancer cells could be regulated by hyaluronan, which is the major ligand for the CD-44 receptor.

\section{Conclusion}

This study suggested that Ki-67, CD-44 and MDR- 1 can be used to evaluate the degree of differentiation, to predict the prognosis of MEC cases and to detect the resistant cases to chemotherapy.

\section{Conflicts OF InTEREST Disclosure}

No potential conflicts of interest are disclosed. 


\section{REFERENCES}

[1] Adams A, Warner K, Nor JE. Salivary Gland Cancer Stem Cells. Oral Oncol. 2013 September; 49(9): 845-853. https: //doi .org/10.1 016/j.oraloncology . 2013.05.013

[2] Regezi JA, Sciubba JJ, Jordan CK. Oral pathology: clinical pathological correlations). Chapter 8: Salivary gland disease. 6th ed. Amsterdam: Elsevier; 2012. 211-14 p.

[3] Shafer, Hine, Levy. Shafer'S Textbook of Oral Pathology. 7th ed. Rajendran R, Sivapathasundharam B. Editors. Chapter 3: salivary gland tumors. New Delhi: Elsevier. 2012; 329-332.

[4] Adams A, Warner K, Pearson A, et al. ALDH/CD44 identifies uniquely tumorigenic cancer stem cells in salivary gland mucoepidermoid carcinomas. Oncotarget. 2015; 6(29): 26633-50. PMid:26449187. https : //doi.org/10.18632/oncotarget . 57 82

[5] Diehn M, Cho RW, Lobo NA, et al. Association of reactive oxygen species levels and radioresistance in cancer stem cells. Nature. 2009; 458(7239): 780-783. PMid:19194462. https ://doi .org/10.103 8/nature07733

[6] Korkaya H, Paulson A, Charafe JE, et al. Regulation of mammary stem/progenitor cells by PTEN/Akt/beta- catenin signaling. PLoSBiol. 2009; 7: e1000121. PMid:19492080. https://doi.org/10 .1371/journal.pbio. 1000121

[7] Bai S, Clubwala R, Adler E, et al. Salivary Mucoepidermoid Carcinoma: A Multi-Institutional Review of 76 Patients. Head and Neck Pathol. 2013; 7: 105-112. PMid:23080318. https ://doi .org/10 $.1007 / \mathrm{s} 12105-012-0405-0$

[8] Cardoso WP, Denardin OV P, Rapoport A, et al. Proliferating cell nuclear antigen expression in mucoepidermoid carcinoma of salivary glands. Sao Paulo Med J/Rev Paul Med. 2000; 118(3): 69-74.

[9] Dowsett M, Nielsen TO, A'hern R, et al. Assessment of Ki67 in breast cancer: recommendations from the International Ki67 in Breast Cancer working group. Journal of the National Cancer Institute. 2011; 103: 1656-1664. PMid:21960707. https://doi.org/10.1093/ jnci/djr393

[10] Okabe M, Inagaki H, Murase T, et al. Prognostic significance of p27 and Ki-67 expression in mucoepidermoid carcinoma of the intraoral minor salivary gland. Mod Pathol. 2001; 14(10): 1008-10. PMid:11598171. https ://doi.org/10.1038/modpathol.3880 426

[11] Shishegar M, Ashraf MJ, Azarpira N, et al. Salivary gland tumors in maxillofacial region: a retrospective study of 130 cases in a southern Iranian population. Patholog Res Int. 2011; 93: 43-50. https ://doi.org/10.4061/2011/934350

[12] Tadbir AA, Pardis S, Ashkavandi ZJ, et al. Expression of Ki67 and CD105 as Proliferation and Angiogenesis Markers in Salivary Gland Tumors. Asian Pacific J Cancer Prev. 2012; 13(10): 5155-5159. PMid:23244127. https ://doi .org/10.7314/APJCP. 2012.13. 10.5155

[13] Hamai A, Codogno P, Mehrpour M. Cancer stem cells and autophagy: Facts and Perspectives. Journal of Cancer Stem Cell Research. 2014; 2(5): 1. https ://doi .org/10.14343/JCSCR . 2014.2e1005

[14] Liu S, Ow A, Ruan M, et al. Prognostic factors in primary salivary gland mucoepidermoid carcinoma: an analysis of 376 cases in an Eastern Chinese population. Int J Oral Maxillofac Surg. 2014 Jun; 43(6): 667-73.

[15] Oliveira LR, Soave DF, OliveiraCosta JP, et al. Mucoepidermoid carcinoma of the salivary glands in Brazil: clinicopathologicaloutcomes. RevistaCubana de Estomatología. 2012; 49(1): 30-38.

[16] Soave DF, Oliveira da Costa JP, Silveira GG, et al. CD44/CD24 immunophenotypes on clinicopathologic features of salivary glands malignant neoplasms. Diagnostic Pathology. 2013; 8: 29.
PMid:23419168. https://doi.org/10.1186/1746-1596-8-2 9

[17] Zhang L, Xiao R, Xiong J, et al. Activated ERM Protein Plays a Critical Role in Drug Resistance of MOLT4 Cells Induced by CCL25, PLoS One. 2013; 8. https://doi.org/10.1371/journal.pone .0052384

[18] Li C, Heidt DG, Dalerba P, et al. Identification of pancreatic cancer stem cells. Cancer Res. 2007; 67: 1030-1037. PMid:17283135. https://doi .org/10.1158/0008-5472.CAN-06-2030

[19] Al-Hajj M, Wicha MS, Benito HA, et al. Prospective identification of tumorigenic breast cancer cells. ProcNatlAcadSci USA. 2003; 100: 3983-3988. PMid:12629218. https ://doi.org/10.1073/pnas .0530291100

[20] Assimakopoulos D, Kolettas E, Patrikakos G. The role of CD44 in the development and prognosis of head and neck squamous cell carcinomas. Histol. Histopathol. 2002; 17(4): 1269-1281. PMid:12371152.

[21] Chen J, Zhou J, Lu J, et al. Significance of CD44 expression in head and neck cancer: a systemic review and meta-analysis. BMC Cancer 2014; 14: 15. PMid:24410905. https://doi.org/10.1186/14 71-2407-14-15

[22] Cai B, Miao Y, Liu Y, et al. Nuclear Multidrug-Resistance Related Protein 1 Contributes to Multidrug-Resistance of Mucoepidermoid Carcinoma Mainly via Regulating Multidrug-Resistance Protein 1: A Human Mucoepidermoid Carcinoma Cells Model and Spearman's Rank Correlation Analysis. PLoS ONE. 2013; 8(8): e69611. PMid:24013781. https://doi.org/10.1371/journal.pone.0 069611

[23] Yin JY, Huang Q, Yang Y, et al. Characterization and analyses of multidrug resistance-associated protein 1 (MRP1/ABCC1) polymorphisms in Chinese population. Pharmacogenetics and Genomics. 2009; 19(3): 206-216. PMid:19214144. https ://doi.org/10.1 $097 / F P C .0 b 013 e 328323 f 680$

[24] Jin Y, Zhang W, Wang H, et al. EGFR/HER2 inhibitors effectively reduce the malignant potential of MDR breast cancer evoked by P-gp substrates in vitro and in vivo. Oncology Reports. 2016; 35(2): 771778. PMid:26718028. https://doi.org/10.3892/or. 2015.44 44

[25] Sobin LH, Gospodarowicz M, Wittekind C. UICC TNM Classification of Malignant Tumors, 7th ed. Hoboken, New Jersey: John Wiley \& Sons, Ltd; 2009. 54-5 p.

[26] Edge SB, Byrd DR, Compton CC, et al. American Joint Committee on Cancer (AJCC). Cancer Staging Manual. 7th ed. New York: Springer; 2009.

[27] Demichelis F, Barbareschi M, Dalla PP, et al. The virtual case: a new method to completely digitize cytological and histological slides. Virchows Arch. 2002; 441: 159-164. https://doi.org/10.100 7/s00428-001-0561-1

[28] Suresh D, Raviraj J, Vijaykumar B, et al. Central mucoepidermoid carcinoma of the maxilla with unusual ground glass appearance and calcifications: A case report. Imaging Science in Dentistry. 2014; 44(2): 161-164. PMid:24944967. https://doi.org/10.5624/is d. 2014.44.2.161

[29] Varma S, Shameena P, Sudha S, et al. Clear cell variant of intraosseous mucoepidermoid carcinoma: report of a rare entity. J Oral Maxillofac Pathol. 2012; 16: 141-4. PMid:22438653. https : //doi.org/10.4103/0973-029X.92994

[30] Kaza S, Rao TJM, Mikkilineni A, et al. Ki-67 Index in Salivary Gland Neoplasms. Int J PhonosurgLaryngol. 2016; 6(1): 1-7.

[31] Siddique S, Din H, Hashmi SN, et al. Role of Ki-67 in the Grading of Mucoepidermoid Carcinomas. Journal of Rawalpindi Medical College. 2015; 19(2): 120-123. 
[32] Luukkaa H, Klemi P, Leivo I, et al. Salivary gland cancer in Finland 1991-96: an evaluation of 237 cases. Acta Otolaryngol. 2005; 125 : 207-214. PMid:15880955. https ://doi.org/10.1080/000164 80510003174

[33] Triantafillidou K, Dimitrakopoulos J, Iordanidis F, et al. Mucoepidermoid carcinoma of minor salivary glands: a clinical study of 16 cases and review of the literature. Oral Diseases. 2006; 12: 364-370. PMid:16792720. https : //doi.org/10.1111/j.1601-0825.20 $05.01166 . \mathrm{x}$

[34] Skalova A, Lehtonen H, Von Boguslawsky K, et al. Prognostic significance of cell proliferation in mucoepidermoid carcinomas of the salivary gland: clinicopathological study using MIB1 antibody in paraffin sections. Hum Pathol. 1994; 25: 929-35.

[35] Faur AC, Sas I, Marius M, et al. Ki-67 and p53 immunostaining assessment of proliferative activity in salivary tumors. Rom J MorpholEmbryol. 2015; 56(4): 1429-1439. PMid:26743291.

[36] Hicks J, Flaitz C. Mucoepidermoid carcinoma of salivary glands in children and adolescents: assessment of proliferation markers. Oral Oncol. 2000 Sep; 36(5): 454-60. https ://doi.org/10.1016/S1 368-8375 (00) 00033-6

[37] Bonhin RG, de Carvalho GM, Guimarães AC, et al. Histologic correlation of expression of $\mathrm{Ki}-67$ in squamous cell carcinoma of the glottis according to the degree of cell differentiation. Braz J Otorhinolaryngol. 2014; 80: 290-5. PMid:25183178. https://doi .org/ 10.1016/j.bjorl.2014.05.016

[38] Kim SY, Kang JW, Song X, et al. Role of the IL-6-JAK1-STAT3Oct-4 pathway in the conversion of non-stem cancer cells into cancer stem-like cells. Cellular Signal. 2013; 25: 961-969. PMid:23333246. https://doi.org/10.1016/j.cellsig.2013.01.007

[39] Maeda K, Chung YS, Onoda N, et al. Proliferating cell nuclear antigen labeling index of preoperative biopsy specimens in gastric carcinoma with special reference to prognosis. 1994; 73(3): 528-533.

[40] Binmadi N, Elsissi A, Elsissi N. Expression of cell adhesion molecule CD44 in mucoepidermoid carcinoma and its association with the tumor behavior. Head \& Face Medicine. 2016; 12: 8. PMid:26821610. https ://doi.org/10.1186/s13005-016-0102-4

[41] Rodrigo JP, Domínguez F, Alvarez C, et al. Clinicopathologic Significance of Expression of CD44s and CD44v6 Isoforms in Squamous Cell Carcinoma of the Supraglottic Larynx. Am J Clin Pathol. 2002; 118: 67-72. PMid:12109858. https://doi.org/10.1309/F50H -6MLG-R7LM-2XFT
[42] Jang MH, Kang HJ, Jang KS, et al. Clinicopathological analysis of CD44 and CD24 expression in invasive breast cancer. Oncology Letters. 2016; 12: 2728-2733. PMid:27698848. https : //doi.org/10.3892/ol.2016.4987

[43] Spafford MF, Koeppe J, Pan Z. Correlation of tumor markersp53, bcl2, CD34, CD44H, CD44v6, and Ki-67 with survivaland metastasis in laryngeal squamous cell carcinoma. Arch Otolaryngol Head Neck Surg. 1996; 122: 627-32. PMid:8639294. https ://doi .org/10.1 001/archotol.1996.01890180035010

[44] Furusaka T, Sasaki CT, Matsuda A, et al. Multidrug resistance in mucoepidermoid carcinoma of the parotid gland-immunohistochemical investigations of P-glycoprotein expression. Acta OtoLaryngologica. 2013; 133(5): 552-557. PMid:23350593. https ://doi .org/10.3 109/00016489.2012.749521

[45] Yang X, Uziely B, Groshen S, et al. MDR1 gene expression in primary and advanced breast cancer. Lab Invest. 1999 Mar; 79(3): 27180.

[46] Li DW, Goa S, Shen B, et al. Effect of apoptotic and proliferative indices, P-glycoprotein and survivin expression on prognosis in laryngeal squamous cell carcinoma. Med Oncol. 2011; 28: S33340. PMid:20862566. https://doi.org/10.1007/s12032-010 $-9686-\mathrm{x}$

[47] Lu LS, Chen L, Ding WX, et al. Elevated expression of both MDR1 and MMP-2 genes in metastasized lymph node of invasive ductal breast cancer. Europ. Review for Medi. and Pharmaco. Sciences. 2012; 16: 2037-2043.

[48] Booth DG, Takagi M, Sanchez-Pulido L, et al. Ki-67 is a PP1interacting protein that organises the mitotic chromosome periphery. elife research article. Cell biology. eLife. 2014; 3: e01641.

[49] Zhang L, Li L, Wang Y, et al. MC3 Mucoepidermoid carcinoma cell line enriched cancer stem-like cells following chemotherapy. Oncology Letters. 2014; 7(5): 1569-1575. PMid:24765178. https : //doi.org/10.3892/ol.2014.1902

[50] Yildiz E, Gokce G, Kilicarslan H, et al. Prognostic value of the expression of Ki-67, CD44 and vascular endothelial growth factor, and microvessel invasion, in renal cell carcinoma. 2004; 93: 1087-109.

[51] Misra S, Ghatak S, Zoltan-Jones A, et al. Regulation of multidrug resistance in cancer cells by hyaluronan. J Biol Chem. 2003; 278: 25285-25288. https : //doi.org/10.1074/jbc.C300173200 